\title{
High Frequency Oscillatory Ventilation Suppresses Inflammatory Response in Lung Tissue and Microdissected Alveolar Macrophages in Surfactant Depleted Piglets
}

\author{
KATHARINA VON DER HARDT, MICHAEL ANDREAS KANDLER, LUDGER FINK, \\ ELLEN SCHOOF, JÖRG DÖTSCH, OLGA BRANDENSTEIN, RAINER MARIA BOHLE, AND \\ WOLFGANG RASCHER \\ Universitätsklinik für Kinder und Jugendliche, Loschgestr.15, D-91054 Erlangen, Germany [K.v.d.H., \\ M.A.K., E.S., J.D., W.R.], Institut für Pathologie, Universität Gießen, Langhansstr.10, D-35392 Gießen, \\ Germany [L.F., R.M.B.].
}

\begin{abstract}
The impact of high frequency oscillatory ventilation (HFOV) compared with intermittent mandatory ventilation (IMV) on oxygenation and pulmonary inflammatory response was studied in a surfactant depleted piglet model. After establishment of lung injury by bronchoalveolar lavage, piglets either received HFOV $(n=5)$ or IMV (control; $n=5$ ) for eight hours. $\mathrm{PaO}_{2}$ was higher and mean pulmonary arterial pressure (MPAP) was lower with HFOV (HFOV versus control, mean $\pm \mathrm{SEM}$; endpoint $\mathrm{paO}_{2}: 252 \pm 73$ versus 68 $\pm 8.4 \mathrm{~mm} \mathrm{Hg} ; p<0.001$; MPAP: $22 \pm 2.3$ versus $34 \pm 2.5 \mathrm{~mm}$ $\mathrm{Hg} ; p<0.01$ ). mRNA expression of interleukin (IL)-1 $\beta$, IL-6, IL-8, IL-10, TGF- $\beta 1$, Endothelin-1, and adhesion molecules (E-selectin, P-selectin, ICAM-1) in lung tissue was quantified by real time PCR normalized to $\beta$-actin and hypoxanthine-guanine-phosphoribosyltransferase (HPRT). mRNA expression of all cytokines and adhesion molecules/HPRT was higher in controls (e.g.: HFOV versus control, mean \pm SEM; IL-1 $\beta /$ HPRT: $1.6 \pm 0.3$ versus $23.1 \pm 8.6$ relative units (RU), $p<0.001$; IL-8/HPRT: $8.5 \pm 2.0$ versus 63.5 $\pm 15.2 \mathrm{RU}, p<0.001)$. IL-8/HPRT gene expression was quantified in microdissected single cells. With HFOV, IL-8 gene expression was highly reduced in alveolar macrophages: $10 \pm 3.4$ copies IL-8
\end{abstract}

\section{ABSTRACT}

mRNA/copy HPRT mRNA versus $356 \pm 142 ; p<0.05$ (bronchiolar epithelial cells: $33 \pm 16$ versus $208 \pm 108$; alveolar septum: 2.1 \pm 1.3 versus $26 \pm 11$; bronchiolar smooth muscle cells: $1.3 \pm 0.3$ versus $2.8 \pm 1.0$; vascular smooth muscle cells: $0.7 \pm 0.3$ versus 1.1 \pm 0.4 ). In conclusion, HFOV improved oxygenation, reduced pulmonary arterial pressure and attenuated pulmonary inflammatory response. (Pediatr Res 55: 339-346, 2004)

$\quad$ Abbreviations
A, $\beta$-actin
BPD, bronchopulmonary dysplasia
FiO $_{2}$, inspiratory fraction of oxygen
HFOV, high frequency oscillatory ventilation
HPRT, hypoxanthine-guanine-phosphoribosyl-transferase
ICAM-1, intercellular adhesion molecule-1
IMV, intermittent mandatory ventilation
MPAP, mean pulmonary arterial pressure
RU, relative units
TGF- $\beta 1$, transforming growth factor- $\beta 1$

Chronic lung disease may develop in patients receiving long term and intensive respiratory support (1). Barotrauma, volutrauma, oxygen toxicity and pulmonary infections are crucial factors perpetuating lung injury. Several mediators of inflammation have been identified in the complex inflammatory

Received February 27, 2003; accepted July 31, 2003.

Correspondence: K. von der Hardt, M.D., Universitätsklinik für Kinder und Jugendliche, Loschgestr. 15, D-91054 Erlangen, Germany; e-mail: k.vonderhardt@web.de

Supported by grant of the IZKF (Interdisziplinäres Zentrum für Klinische Forschung), University Erlangen-Nuernberg, and the Deutsche Forschungsgemeinschaft (Sonderforschungsbereich 547, project Z1).

K.v.d.H. and M.A.K. contributed equally to this work.

DOI: 10.1203/01.PDR.0000106802.55721.8A network. Among others, IL- $1 \beta$, IL- 8 and TGF- $\beta$ were found to be elevated in bronchoalveolar lavage fluid of infants developing bronchopulmonary dysplasia $(1,2)$. Adhesion molecules such as intercellular adhesion molecule (ICAM)-1, E- and P-selectin are important for leukocyte attraction and penetration into inflamed tissue $(3,4)$. To improve respiratory support and to diminish the risk of chronic lung disease, high frequency oscillatory ventilation (HFOV) has been developed as rescue and lung protective ventilation strategy. Chronic lung disease could be reduced in preterm infants using HFOV in combination with surfactant and a defined strategy to improve alveolar recruitment $(5,6,7)$. However, no final consensus on improvement of clinical outcome has been achieved $(8,9)$. Animal 
studies on reduction of pulmonary inflammatory response by HFOV are limited and their designs different. In surfactantdepleted rabbits, 6-keto-prostaglandin F1 alpha, thromboxane B2, platelet-activating factor, and the numbers of polymorphonuclear leukocytes in bronchoalveolar lavage fluid were reduced after four hours of HFOV (10). In surfactant depleted rabbits, a four hours HFO-ventilation period reduced protein concentration, elastase activity, and TNF- $\alpha$ concentration in tracheal fluid and myeloperoxidase activity in lung homogenates $(11,12)$. In these studies however, mean airway pressure was different between the groups. In another study in surfactant depleted rabbits, using identical mean airway pressure with $\mathrm{HFOV}$ and $\mathrm{CMV}$, treatment started at $\mathrm{PaO}_{2}$ levels $>350 \mathrm{~mm} \mathrm{Hg}$ (13), suggesting less severe lung injury. In this study, the number of neutrophils in lung lavage fluid and neutrophil accumulation was lower after four hours of HFOV compared with conventional ventilation. Additionally, TNF mRNA expression in lung lavage fluid was reduced after $1 \mathrm{~h}$ of HFOV (13). Another study comparing HFOV with CMV used identical mean airway pressure in the groups, but a PEEP of $0 \mathrm{~cm}$ $\mathrm{H}_{2} \mathrm{O}$ in the CMV group. This results in a traumatic ventilation mode in the CMV group. Less granulocyte infiltration and lower 2-integrin expression on granulocytes and macrophages was shown in the HFOV group (14). HFOV for 1-2 mo in immature baboons (15) improved pulmonary mechanics during the first four weeks. IL-8 concentrations in tracheal aspirates were lower from days 6-10. To further assess the influence of HFOV on gas exchange and lung injury, we compared HFOV to conventional ventilation in a neonatal, surfactant depleted piglet model with severe ARDS, using identical mean airway pressure in both groups and moderately high PEEP in the CMV group to avoid less effective or extremely traumatic CMV ventilation settings. For evaluation of pulmonary inflammatory response (16), we assessed gene expression of IL-1 $\beta$, IL-6, IL-8, IL-10, Endothelin-1, TGF$\beta 1$, E-selectin, P-selectin and ICAM-1 in lung tissue of piglets receiving either HFOV or IMV. These cytokines have previously been shown to be regulated in this model of lung injury after $8 \mathrm{~h}$ of ventilation $(4,16)$. To further elucidate the mechanism and to define the relative contribution of specific pulmonary cells to the inflammatory response, we determined mRNA expression of IL-8 in alveolar macrophages, bronchiolar epithelial cells, bronchiolar and vascular smooth muscle cells and cells of the alveolar septum. Microdissection techniques were used allowing for a cell-type specific mRNA analysis within complex tissues $(17,18,19)$.

\section{MATERIAL AND METHODS}

The study was approved by the Animal Care Committee of the university and the government of Mittelfranken, Germany, and performed according to the guidelines of the National Institutes of Health. Ten piglets (body weight $3.5-4.3 \mathrm{~kg}$ ) were included. For evaluation, one HFOV piglet was excluded due to preexisting infection. One control piglet was excluded for mRNA evaluation, due to degraded mRNA.

\section{Treatment Groups}

Anesthesia and operative preparation were performed as described previously $(16,20,21)$. Briefly, animals were tracheotomized and intubated $(4.0 \mathrm{~mm}$ endotracheal tube,
Mallinckrodt, Hennef, Germany). A catheter $\left(20 \mathrm{G}\right.$, Arrow ${ }^{\circledR}$, Erding, Germany) was introduced into the left femoral artery to measure arterial pressure and arterial oxygen tension (ABL 330, Radiometer, Copenhagen, Denmark). For registration of pulmonary arterial pressure, a catheter $\left(4 \mathrm{~F}\right.$, Arrow ${ }^{\circledR}$, Erding, Germany) was inserted via a jugular sheath $(4.5 \mathrm{~F}$, check-flo performer ${ }^{\circledR}$ introducer set, Cook ${ }^{\circledR}$, Mönchengladbach, Germany) into the pulmonary artery. IMV was performed with a time cycled pressure controlled neonatal respirator (Infant Star 950, Mallinckrodt ${ }^{\circledR}$, Hennef, Germany) starting with a peak inspiratory pressure of $20 \mathrm{~cm} \mathrm{H}_{2} \mathrm{O}$, a positive end expiratory pressure of $4 \mathrm{~cm} \mathrm{H}_{2} \mathrm{O}$, an inspiratory fractional oxygen concentration $\left(\mathrm{FiO}_{2}\right)$ of 1.0 and a frequency of 40 breaths $/ \mathrm{min}$, augmented to 50 breaths/min before lavage, using an I:E ratio of 1:1.4. Respiratory gas was warmed and humidified. Lung injury was induced by saline lung lavage (22) and considered successful when $\mathrm{paO}_{2}$ remained below $80 \mathrm{~mm} \mathrm{Hg}$ for $60 \mathrm{~min}$. During lavage, peak inspiratory pressure and positive end expiratory pressure were increased to 32 and $8 \mathrm{~cm} \mathrm{H}_{2} \mathrm{O}$, respectively.

After establishment of lung injury, animals were randomized to two therapy groups. In the IMV group, respiratory support was continued with identical respiratory settings. After establishment of lung injury, animals of the HFOV group were switched to HFOV (Sensormedics 3100A, VIASYS, Yorba Linda, U.S.A.), applying an identical mean airway pressure as in the IMV group (continuous distension pressure $=17.8 \mathrm{~cm}$ $\mathrm{H}_{2} \mathrm{O}$ ), an amplitude of $35 \mathrm{~cm} \mathrm{H}_{2} \mathrm{O}$, an oscillatory frequency of $10 \mathrm{~Hz}$, a fractional inspiratory time of $33 \%$ and an $\mathrm{FiO}_{2}$ of 1.0 . After $8 \mathrm{~h}$ of ventilation, animals were killed. Eight samples of corresponding parts of the lung were chosen for mRNA analysis. After instillation of tissue-freezing medium (Leica ${ }^{\circledR}$, Nussloch, Germany) two samples of the inferior lobe were asserved for microdissection analysis.

\section{Cytokine Gene Expression in Lung Tissue Homogenates}

In nonmicrodissected lung tissue, RNA extraction, reverse transcription and TaqMan real time PCR (23) were performed as described previously $(4,16,21)$. Gene expression was related to the housekeeping genes $\beta$-actin (A) and hypoxanthine-guanine-phosphoribosyl-transferase (HPRT). Primers and TaqMan probes were specifically designed for the porcine model and are listed in Table 1.

\section{Cytokine Gene Expression in Microdissected Cells}

Cryostat sectioning and staining. $10 \mu \mathrm{m}$ sections of tissuefreezing medium embedded lung tissue samples were prepared in a cryotome $\left(\right.$ Leica $\left.{ }^{\circledR}\right)$ mounted on glass slides $(0.17 \mathrm{~mm}$ thickness) and immersed in $70 \%, 90 \%$ and $100 \%$ ethanol. Staining was performed for $60 \mathrm{~s}$ in hemalaun.

Laser-assisted microdissection. Cell picking was performed as described in detail recently $(18,19,24)$. The UV-laser microbeam (P.A.L.M. ${ }^{\circledR}$, Bernried, Germany) used for microdissection consists of a nitrogen laser of high-beam precision (wavelength $337 \mathrm{~nm}$ ), which is coupled to an inverted microscope (Axiovert 135, Zeiss ${ }^{\circledR}$, Jena, Germany) via the epifluorescence illumination path. Microscope stage and micromanip- 
Table 1. Primers and TaqMan probes used for TaqMan real time PCR

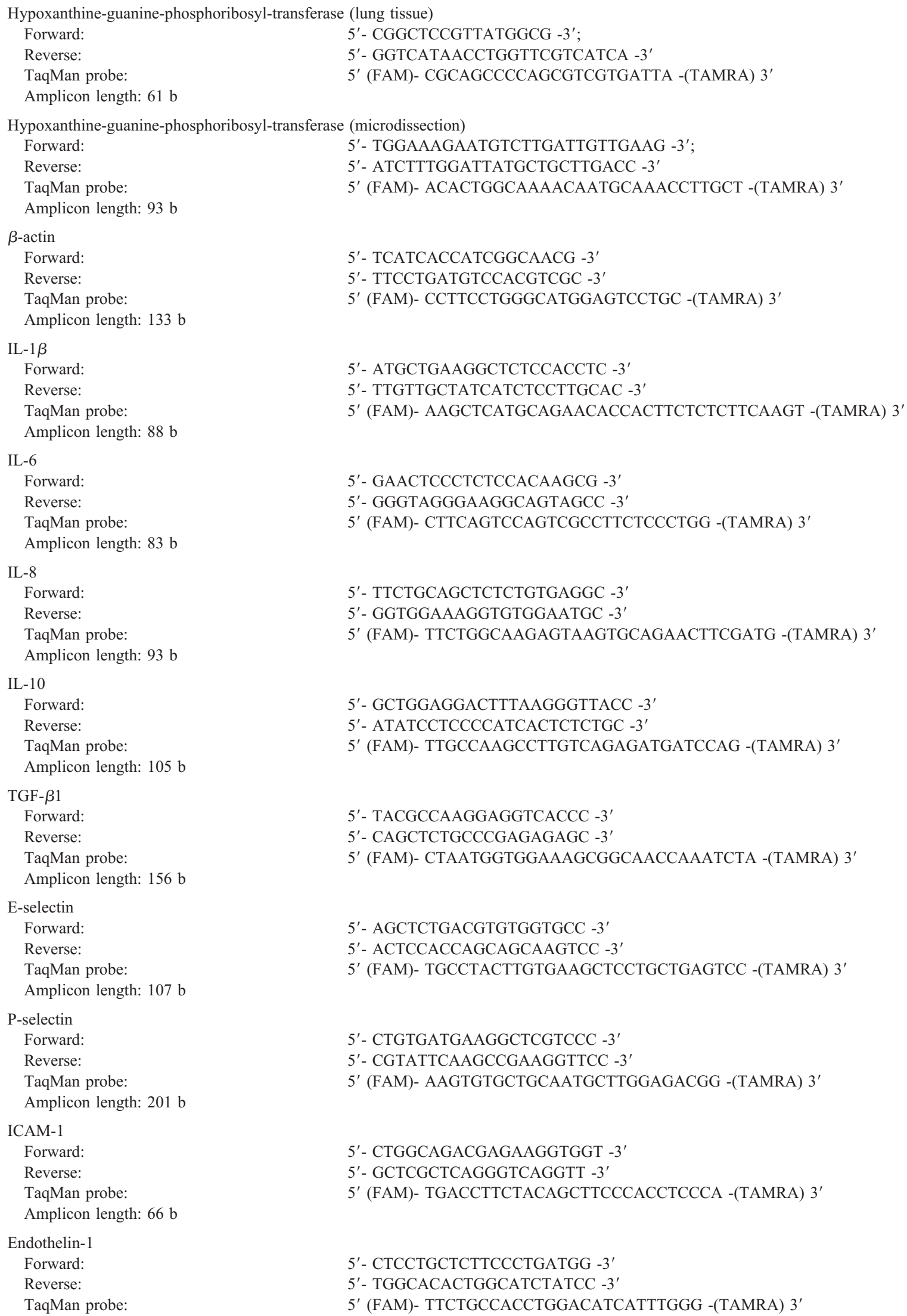

$$
\text { 5' - TGGAAAGAATGTCTTGATTGTTGAAG -3'; }
$$


ulator are digitally controlled and moved by computer mouse. Alveolar macrophages, bronchiolar epithelial cells, endothelial cells, smooth muscle cells of bronchi and blood vessels as well as alveolar septum were identified by light microscopy. Adjacent tissue was removed by UV-laser-photolysis under visual control. A sterile needle linked to the micromanipulator served for picking the cell(s) via adhesive forces with direct transfer into a reaction tube (Fig. 1). Needles with the adherent cell(s) were transferred into a reaction tube containing $10 \mu \mathrm{L}$ of first strand buffer (FSB) (52mM Tris-HCl, $\mathrm{pH} 8.3,78 \mathrm{mM} \mathrm{KCl}$ and $3.1 \mathrm{mM} \mathrm{MgCl} 2$ ). Per tube, 16 alveolar macrophages, approximately 20 bronchiolar epithelial cells or 3 circles of bronchiolar or vascular smooth muscle cells were collected. Specimens were immediately frozen in liquid nitrogen.

Reverse transcription. cDNA synthesis was performed within $12 \mathrm{~h}$ after cell-picking using products purchased from Perkin-Elmer ${ }^{\circledR}$ (Zaventem, Belgium) $(10 \times$ PCR-buffer II, $\mathrm{MgCl}_{2}$, random hexamers, RNAse inhibitor, MMLV reverse transcriptase) and Eurobio ${ }^{\circledR}$ (dNTPs, Raunheim, Germany). Tubes with picked cells were heated to $70^{\circ} \mathrm{C}$ for $10 \mathrm{~min}$ and then cooled on ice for 5 min. For cDNA synthesis, $2 \mu \mathrm{L}$ PCR-buffer II, $2 \mu \mathrm{L} \mathrm{MgCl}_{2}, 1 \mu \mathrm{L}$ dNTP $(10 \mu \mathrm{M}$ each), $1 \mu \mathrm{L}$ random hexamers $(50 \mu \mathrm{M}), 1 \mu \mathrm{L}$ MMLV reverse transcriptase, $1 \mu \mathrm{L} \mathrm{H}_{2} \mathrm{O}$ and $0.5 \mu \mathrm{L}(5 \mathrm{U})$ RNase inhibitor were added to a total volume of $18.5 \mu \mathrm{L}$. Samples were incubated at $20^{\circ} \mathrm{C}$ for $10 \mathrm{~min}$ and $43^{\circ} \mathrm{C}$ for $70 \mathrm{~min}$. Reactions were stopped by heating to $95^{\circ} \mathrm{C}$ for $5 \mathrm{~min}$.

Relative mRNA Quantitation by TaqMan real time PCR. Efficiency and reliability of this method after laser assisted cell picking (19) have been shown earlier (18). After cDNA synthesis, each sample was devided for analysis of IL-8 as target gene and HPRT as housekeeping gene into two aliquots of 8 $\mu \mathrm{L}$. The TaqMan Universal Master Mix (Perkin-Elmer ${ }^{\circledR}$ ) was used according to the manufacturer's protocol. $8 \mu \mathrm{L}$ of cDNA (reverse transcription mixture) and oligonucleotides with a final concentration of $900 \mathrm{nM}$ of primers and $200 \mathrm{nM}$ of hybridization probe were added to $50 \mu \mathrm{L}$ reaction mix. Primers and probes were purchased from Eurogentec ${ }^{\circledR}$ (Seraing, Belgium). The thermocycler parameters were $50^{\circ} \mathrm{C}$ for $2 \mathrm{~min}$ and $95^{\circ} \mathrm{C}$ for $6 \mathrm{~min}$, followed by 55 cycles of $95^{\circ} \mathrm{C}$ for $20 \mathrm{~s}$ and $60^{\circ} \mathrm{C}$ and $73^{\circ} \mathrm{C}$ for $30 \mathrm{~s}$ each. Primers and TaqMan probes used are listed in Table 1 .

For relative quantitation, comparative $\mathrm{C}_{\mathrm{T}}$ method normalizes the number of target gene copies to HPRT as endogenous reference. For evaluation of target gene mRNA expression in relation to housekeeping gene mRNA expression, the difference of $\mathrm{C}_{\mathrm{T}}$ values between housekeeping gene and target gene was calculated, potentiated to the base 2 and compared between the different treatment groups (19).

Only samples with detection of both, target gene and housekeeping gene, were included in the analysis. Microdissection procedure was repeated until housekeeping gene and target gene mRNA were both detectable in the identical sample.

Data analysis. Data analysis was performed with Microsoft EXCEL ${ }^{\circledR}$ and Graph Pad PRISM ${ }^{\circledR}$. Values are expressed as mean \pm SEM. Depending on the presence of Gaussian distribution, either the $t$ test or Mann-Whitney test was used for comparison of the groups. A p-value of less than 0.05 was

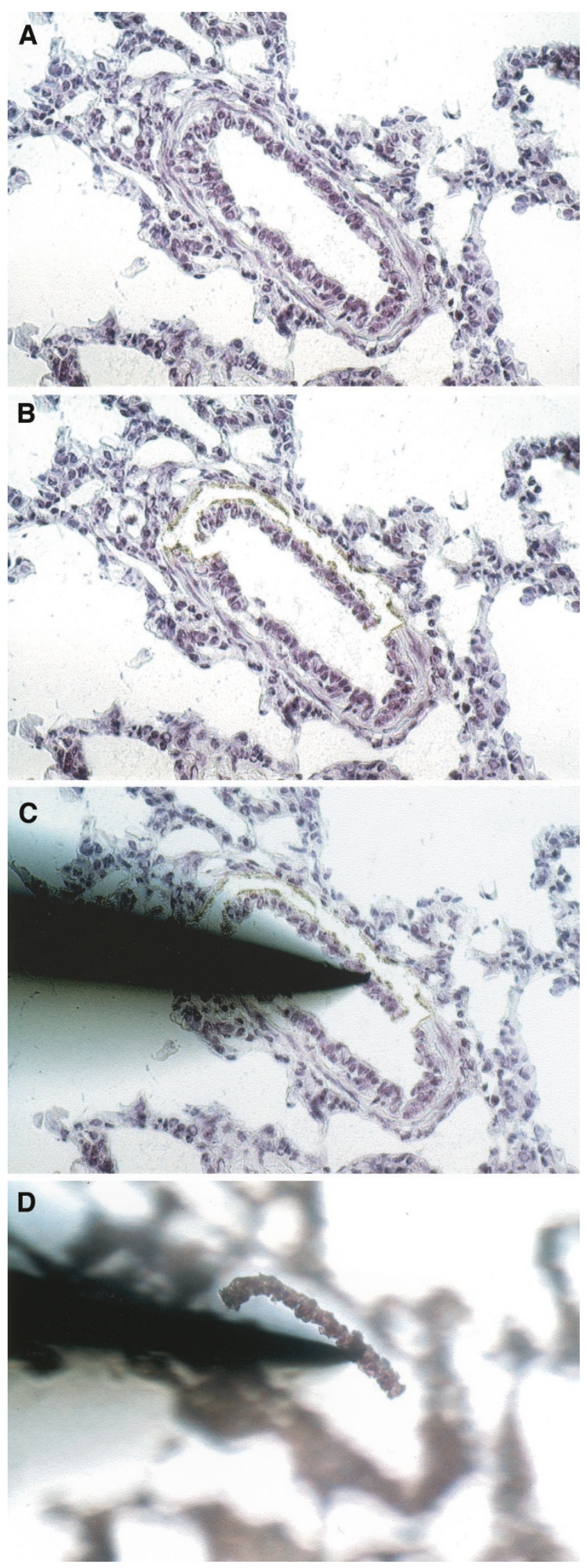

Figure 1. Laser-assisted microdissection. Bronchiolar epithelial cells, hemalaun-stained tissue sections, magnification 40 fold. $(A)$ identification, $(B)$ after laserphotolysis of adjacent tissue, $(C)$ needle in place, $(D)$ dislocation of bronchiolar epithelial cells by needle. 
considered significant. Values are given as mean \pm SEM, HFOV versus control group.

\section{RESULTS}

\section{Gas Exchange and $\mathrm{pH}$}

Pulmonary gas exchange improved significantly in the HFOV group. Endpoint values were: $\mathrm{PaO}_{2}: 252 \pm 73$ versus $68 \pm 8.4 \mathrm{~mm} \mathrm{Hg} ; p<0.001 . \mathrm{PaCO}_{2}: 37.0 \pm 5.3$ versus 60.6 $\pm 5.1 \mathrm{~mm} \mathrm{Hg} ; p<0.001 . \mathrm{pH}: 7.50 \pm 0.06$ versus $7.30 \pm 0.04$; $p<0.001$ (Fig. $2 A-C$ ).

\section{Hemodynamic Parameters}

Mean pulmonary arterial pressure (MPAP) was lower with HFOV. Endpoint MPAP was $21.7 \pm 2.3 \mathrm{~mm} \mathrm{Hg}$ in the HFOV and $34.0 \pm 2.5 \mathrm{~mm} \mathrm{Hg}$ in the control group, $p<0.01$ (Fig. 2d).

Mean systemic arterial pressure (MAP) was not different between both groups (at the end of treatment: $61.0 \pm 3.6 \mathrm{~mm}$ $\mathrm{Hg}$ in the HFOV and $58.0 \pm 4.5 \mathrm{~mm} \mathrm{Hg}$ in the control group).

\section{Cytokine Gene Expression}

Normalized to both housekeeping genes, mRNA expression of IL-1 $\beta$, IL-8, IL-10, P-selectin and ICAM-1 was reduced in the HFOV group. mRNA expression of IL-6, E-selectin, Endothelin- 1 and TGF- $\beta 1$ was reduced in the HFOV group only when normalized to HPRT (Table 2 and Fig. 3).
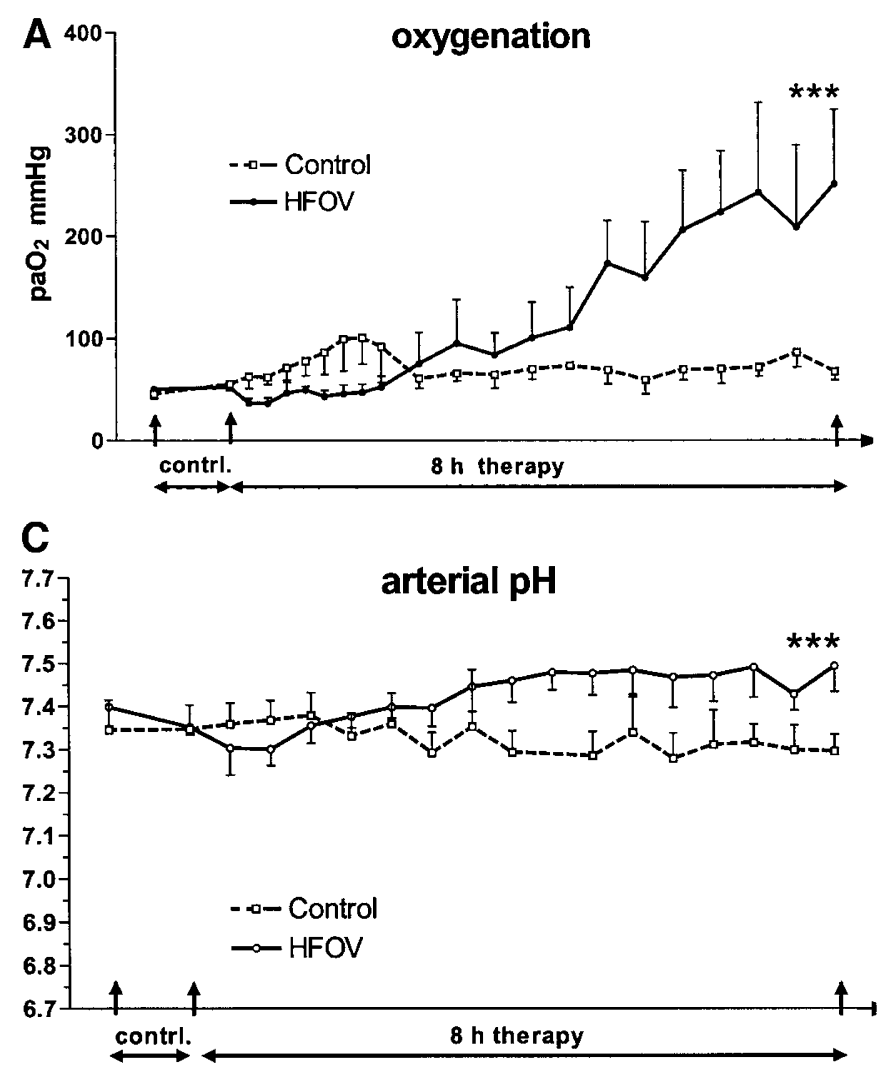

\section{Laser-Assisted Microdissection}

HPRT $\boldsymbol{m R N A}$ expression. HPRT mRNA was detectable in $64 \%$ of alveolar macrophage specimens, in $100 \%$ of bronchiolar epithelial cell, in $81 \%$ of alveolar septum, in $100 \%$ of bronchiolar and $94 \%$ of vascular smooth muscle cell specimens.

IL-8 mRNA expression: IL-8 mRNA was detectable in $78 \%$ of alveolar macrophage specimens, in $92 \%$ of bronchiolar epithelial cell, $69 \%$ of alveolar septum, $88 \%$ of bronchiolar smooth muscle cell and $77 \%$ of vascular smooth muscle cell specimens.

With HFOV, IL-8 gene expression was highly reduced in alveolar macrophages: $10 \pm 3.4$ copies IL-8 mRNA/copy HPRT mRNA versus $356 \pm 142 ; p<0.05$. In bronchiolar epithelial cells $(33 \pm 16$ copies IL-8 mRNA/copy HPRT mRNA versus $208 \pm 108)$, alveolar septum $(2.1 \pm 1.3$ copies IL-8 mRNA/copy HPRT mRNA versus $26 \pm 11$ ), bronchiolar smooth muscle cells $(1.3 \pm 0.3$ copies IL-8 mRNA/copy HPRT mRNA versus $2.8 \pm 1.0$ ) and vascular smooth muscle cells $(0.7 \pm 0.3$ copies IL- $8 \mathrm{mRNA}$ /copy HPRT mRNA versus $1.1 \pm 0.4)$ this difference was not significant. Within both groups, maximum IL-8 mRNA expression was found in alveolar macrophages, followed by bronchiolar epithelial cells, alveolar septum, bronchiolar smooth muscle cells and was lowest in vascular smooth muscle cells $(p<0.05$ for IL-8
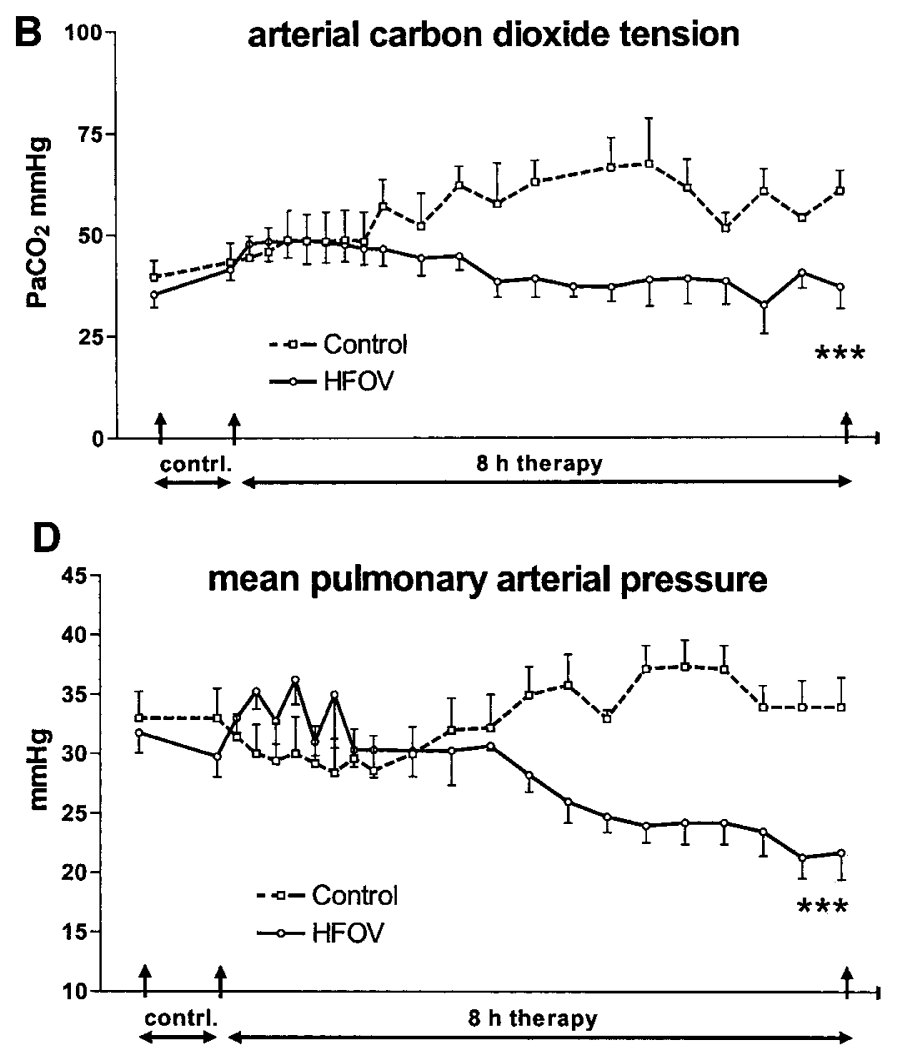

Figure 2. Arterial oxygen tension $\left(\mathrm{PaO}_{2}\right)(A)$ arterial carbon dioxide tension $\left(\mathrm{PaCO}_{2}\right)(B)$ arterial $\mathrm{pH}(C)$ and mean pulmonary arterial pressure $(\mathrm{MPAP})(D)$ in surfactant depleted piglets obtained after induction of lung injury, during a control period of $1 \mathrm{~h}$ and during $8 \mathrm{~h}$ of therapy with either high frequency oscillatory ventilation (HFOV) or intermittent mandatory ventilation (control). $* * * p<0.001$. 
mRNA expression in alveolar macrophages versus bronchiolar and vascular smooth muscle cells in the control group).

\section{DISCUSSION}

The continuous and significant improvement of oxygenation with HFOV in this model of severe ARDS demonstrates the effectiveness of HFOV, even though neither surfactant nor a lung recruitment strategy was applied. In contrast, no improvement in oxygenation was seen with IMV. It becomes more and more accepted from clinical and experimental work that the difference does probably not depend on the mode of ventilation (HFOV or conventional ventilation) but on the strategy (open lung concept) used (25). Therefore, in the present study a high volume strategy with additional recruitment maneuvers was not used in the HFOV group to ensure comparability between the groups. Besides, mean airway pressure was kept identical in both groups. As the intrapulmonary pressure tends to be lower than the continuous distension pressure set with the HFOV respirator (26), effective mean airway pressure was equal or lower in the HFOV than in the IMV group. This continuous distension pressure was sufficient to oxygenate more effectively than IMV performed with moderately high PEEP. As conventional ventilation with high tidal volume and low PEEP is known to promote lung injury, a PEEP of 8 $\mathrm{cmH}_{2} \mathrm{O}$ was chosen in this model to avoid comparison of HFOV with a known to be harmful respiratory strategy (12, 27). These ventilator settings may be the reason, why physiologic differences between the groups became not obvious

Table 2. $m R N A$ expression (relative units, $R U$ ) of $I L-1 \beta, I L-6, I L-8$, IL-10, TGF- $\beta 1$, Endothelin-1, P-selectin, E-selectin and ICAM-1 normalized to $\beta$-actin in the lung of surfactant depleted piglets after a therapy period of 8 hours with high frequency oscillatory ventilation (HFOV) or intermittent mandatory ventilation (control)

\begin{tabular}{lccccccc}
\hline & \multicolumn{2}{c}{ HFOV } & & \multicolumn{2}{c}{ Control } & \\
\cline { 2 - 3 } & Mean (RU) & SEM & & Mean (RU) & SEM & $p$ \\
\hline IL-1 $\beta / A$ & $8.76 \pm$ & 1.58 & & $85.57 \pm$ & 36.04 & $<0.01$ \\
IL-6/A & $9.34 \pm$ & 2.08 & & $33.70 \pm$ & 10.45 & n.s. \\
IL-8/A & $4.59 \pm$ & 0.93 & & $24.52 \pm$ & 5.83 & $<0.001$ \\
IL-10/A & $3.03 \pm$ & 0.39 & & $10.35 \pm$ & 2.70 & $<0.01$ \\
TGF- $\beta 1 / A$ & $4.19 \pm$ & 0.39 & & $4.88 \pm$ & 0.36 & n.s. \\
ET-1/A & $15.47 \pm$ & 3.95 & & $15.76 \pm$ & 2.17 & n.s. \\
P-selectin/A & $2.33 \pm$ & 0.22 & & $4.0 \pm$ & 0.59 & $<0.05$ \\
E-selectin/A & $1.35 \pm$ & 0.22 & & $6.0 \pm$ & 1.27 & n.s. \\
ICAM-1/A & $2.54 \pm$ & 0.16 & & $4.03 \pm$ & 0.51 & $<0.01$ \\
\hline
\end{tabular}

before about $4 \mathrm{~h}$ of ventilation. No adverse effect of HFOV on systemic blood pressure could be seen. In contrast, mean pulmonary arterial pressure fell. This could be at least partially explained by the opening of atelectatic lung areas with consecutive reperfusion, improvement in oxygenation and pulmonary vasodilation. With HFOV, the principle of ventilating an open lung with minimal tidal volumes to avoid shear stress can most easily be applied as end-expiratory alveolar collapse is definitely avoided. In our model, despite the lack of a recruitment procedure according to the "open lung concept" HFOV minimized lung injury. The response to HFOV in terms of oxygenation became evident after some hours of ventilation.
This may be due to a successive lung recruitment or surfactant recovery with improvement in compliance, that did not happen in the CMV group. The increase in $\mathrm{pH}$ due to the significant reduction in $\mathrm{PaCO}_{2}$ in combination with improved oxygenation might contribute to the differences in pulmonary arterial pressure between the groups. Most of the clinical studies showing benefit from HFOV have applied a high volume strategy in the HFOV and not in the conventionally ventilated group, which may account for some of the differences seen between the groups. Our results are in line with a recently published clinical study showing a reduction of chronic lung disease in preterm infants ventilated with HFOV (6). However, a mean HFOV treatment period as short as three days combined with a switch to conventional ventilation for weaning did not reduce the risk of chronic lung disease in premature infants compared with a nonstandardized conventional ventilation (9).

The comprehensive reduction of inflammatory reaction seen with HFOV is most likely caused by a significant reduction of shear stress using a continuous distension pressure. Shear stress due to high tidal volume ventilation and low PEEP initiates lung injury with stress fractures of capillary endothelium, epithelium and basement membrane. Mechanical damage leads to leakage of fluid, protein, and blood into tissue and air spaces or leakage of air into tissue spaces. This process is followed by an inflammatory response (28). Elevated lung lavage cytokine concentrations were already found after $2 \mathrm{~h}$ of traumatic ventilation in an isolated rat lung model (29). Traumatic effects of shear stress were also proven in cell culture experiments (30-32). However, the proportional contribution of different pulmonary cell types to the inflammatory process in vivo has not yet been elucidated in detail. Further insight in the inflammatory mechanisms, especially identification of cell types responsible for the inflammatory reaction might help in targeting cells for additional anti-inflammatory treatment strategies. The anti-inflammatory effect was seen in the HFOV group even though ventilation with low PEEP (and consecutively high shear stress) was avoided in the IMV group. A more lung protective ventilation strategy according to the "open lung concept" might further reduce lung injury seen with IMV (33). Reduction of pulmonary inflammatory response by HFOV was seen in all proinflammatory cytokines, when normalized to HPRT and in most of them when normalized to $\beta$-actin. Normalization to two housekeeping genes reduces the risk of artificial bias due to possible minimal regulation even of housekeeping genes in the experimental setting. The proinflammatory cytokines involved and regulated in this model of lung injury consist of adhesion molecules, chemoattractant, proinflammatory and profibrotic cytokines. They represent crucial parts of the complex cytokine facet of inflammation and final fibrosis. Higher mRNA expression of the antiinflammatory IL-10 in the IMV group is not contradictory to the anti-inflammatory effect observed with HFOV, as IL-10 is up-regulated as response to lung injury (34). Analysis of mixed lung tissue samples for inflammatory reactions bears the risk of masking cell specific differences in gene expression and does not permit cell-type specific evaluation. Remarkable differences between lung homogenate gene expression and a cell type-specific measurement after microdissection have already 

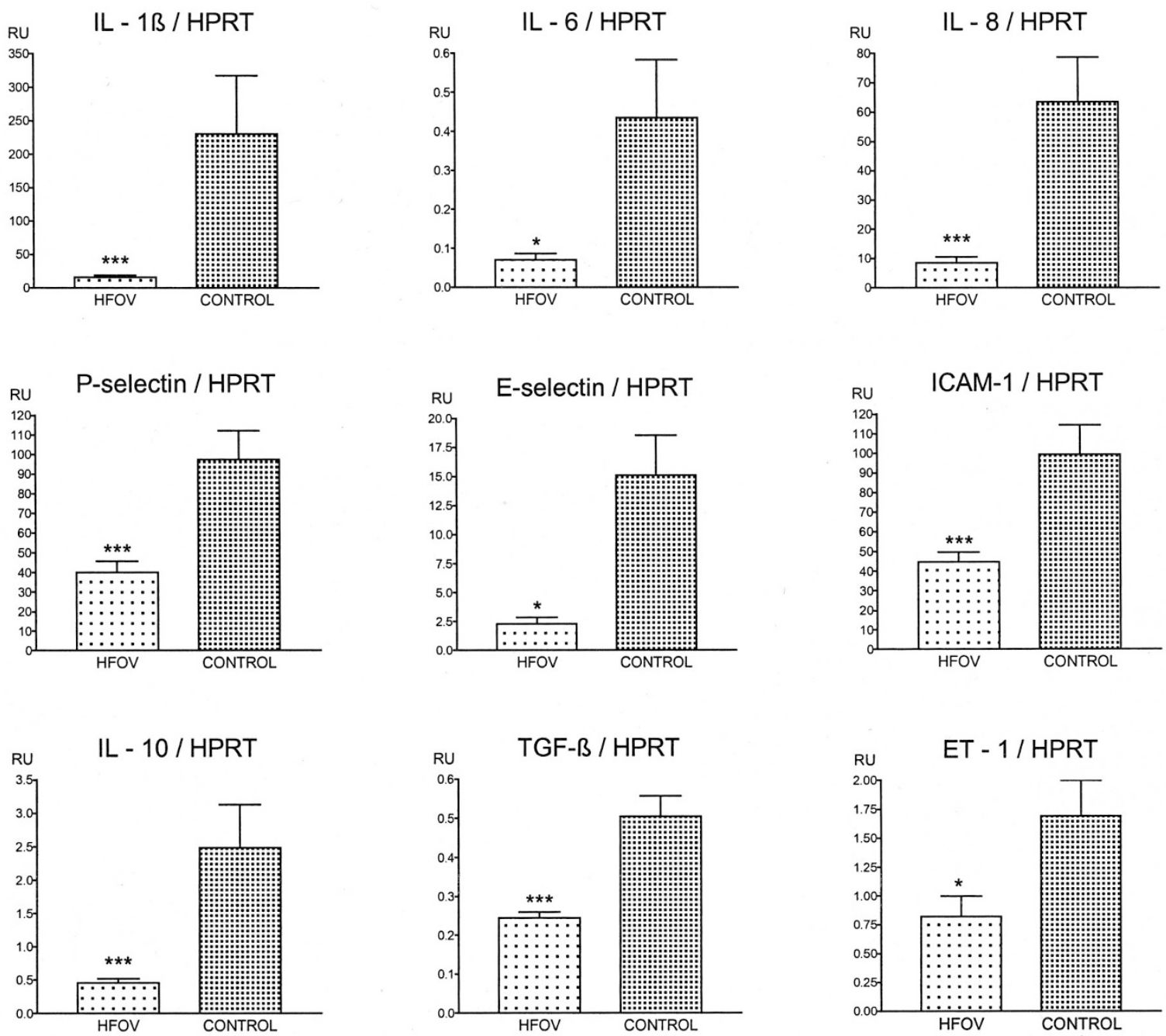

Figure 3. mRNA expression (relative units, RU) of IL-1 $\beta$, IL-6, IL-8, IL-10, TGF- $\beta 1$, ET-1, P-selectin, E-selectin and ICAM-1 normalized to HPRT in the lung of surfactant depleted piglets after a therapy period of $8 \mathrm{~h}$ with high frequency oscillatory ventilation (HFOV) or intermittent mandatory ventilation (control). $* p<0.05 ; * p<0.01 ; * * * p<0.001$.

been demonstrated $(35,36)$. In our study, laser-assisted microdissection and subsequent TaqMan real time PCR allowed cell-specific determination of the localization and regulation of IL-8 production. An up to 30 fold difference in mRNA expression could be detected in alveolar macrophages between the two treatment groups. This confirms, that differences in mRNA expression can be detected in cells obtained by microdissection from identical cryosections and additionally underlines the value of representative results obtained by whole tissue mRNA extraction. Alveolar macrophages could be identified as main cellular source and as site of regulation of IL- 8 expression. Therefore, future anti-inflammatory strategies focusing on alveolar macrophages might be reasonable. Additionally our data show that IL-8 was not exclusively expressed in alveolar macrophages, but in all other cell types studied. Although not significant due to the small number of samples analyzed, a 10-fold reduction of IL-8 mRNA expression with HFOV could also be seen in bronchiolar epithelial cells and - on a 10-fold lower level - in alveolar septum cells.

\section{CONCLUSION}

In summary, treatment of experimental neonatal respiratory distress syndrome with HFOV has not only been shown to improve oxygenation and reduce pulmonary arterial pressure, but also to reduce the early pulmonary inflammatory reaction. This was shown by reduced mRNA expression of IL- $1 \beta$, IL-6, IL- 8 , TGF- $\beta 1$, ET- 1 and the adhesion molecules E-selectin, P-selectin and ICAM-1 in lung tissue. On cellular level, gene expression of IL-8 was shown to be predominantly regulated in alveolar macrophages.

Acknowledgments. The authors thank M.M. Stein, F. Abendroth, S. Brüggemeier, S. Mahfoud, and J. Walther for excellent technical assistance. They also gratefully acknowledge the supply with the Sensormedics by Rolf Schlegelmilch, Medilab, Würzburg, Germany and the excellent support by T. Zocher, Radiometer, Willich, Germany. 


\section{REFERENCES}

1. Speer CP 1999 Inflammatory mechanisms in neonatal chronic lung disease. Eur J Pediatr 158(Suppl 1):S18-22

2. Özdemir A, Brown MA, Morgan WJ 1997 Markers and mediators of inflammation in neonatal lung disease. Pediatr Pulmonol 23:292-306

3. Cotran RS, Mayadas-Norton T 1998 Endothelial adhesion molecules in health and disease. Pathol Biol (Paris) 46:164-170

4. Schoof E, von der Hardt K, Kandler MA, Abendroth F, Papadopoulos T, Rascher W, Dotsch J 2002 Aerosolized perfluorocarbon reduces adhesion molecule gene expression and neutrophil sequestration in acute respiratory distress. Eur J Pharmacol 457:195-200

5. Clark RH, Gerstmann DR, Null DM, Jr., deLemos RA 1992 Prospective randomized comparison of high-frequency oscillatory and conventional ventilation in respiratory distress syndrome. Pediatrics 89:5-12

6. Courtney SE, Durand DJ, Asselin JM, Hudak ML, Aschner JL, Shoemaker CT 2002 High-frequency oscillatory ventilation versus conventional mechanical ventilation for very-low-birth-weight infants. N Engl J Med 347:643-652

7. Gerstmann DR, Minton SD, Stoddard RA, Meredith KS, Monaco F, Bertrand JM Battisti O, Langhendries JP, Francois A, Clark RH 1996 The Provo multicenter early high-frequency oscillatory ventilation trial: improved pulmonary and clinical outcome in respiratory distress syndrome. Pediatrics 98:1044-1057

8. Henderson-Smart DJ, Bhuta T, Cools F, Offringa M 2001 Elective high frequency oscillatory ventilation versus conventional ventilation for acute pulmonary dysfunction in preterm infants. Cochrane Database Syst Rev CD000104

9. Johnson AH, Peacock JL, Greenough A, Marlow N, Limb ES, Marston L, Calvert SA 2002 High-frequency oscillatory ventilation for the prevention of chronic lung disease of prematurity. N Engl J Med 347:633-642

10. Imai Y, Nakagawa S, Ito Y, Kawano T, Slutsky AS, Miyasaka K 2001 Comparison of lung protection strategies using conventional and high-frequency oscillatory ventilation. J Appl Physiol 91:1836-1844

11. Rotta AT, Steinhorn DM 1998 Partial liquid ventilation reduces pulmonary neutrophi accumulation in an experimental model of systemic endotoxemia and acute lung injury. Crit Care Med 26:1707-1715

12. Rotta AT, Gunnarsson B, Fuhrman BP, Hernan LJ, Steinhorn DM 2001 Comparison of lung protective ventilation strategies in a rabbit model of acute lung injury. Crit Care Med 29:2176-2184

13. Takata M, Abe J, Tanaka H, Kitano Y, Doi S, Kohsaka T, Miyasaka K 1997 Intraalveolar expression of tumor necrosis factor-alpha gene during conventional and high-frequency ventilation. Am J Respir Crit Care Med 156:272-279

14. Shimaoka M, Fujino Y, Taenaka N, Hiroi T, Kiyono H, Yoshiya II 1998 High frequency oscillatory ventilation attenuates the activation of alveolar macrophages and neutrophils in lung injury. Crit Care 2:35-39

15. Yoder BA, Siler-Khodr T, Winter VT, Coalson JJ 2000 High-frequency oscillatory ventilation: effects on lung function, mechanics, and airway cytokines in the immature baboon model for neonatal chronic lung disease. Am J Respir Crit Care Med 162:1867-1876

16. von der Hardt K, Schoof E, Kandler MA, Dötsch J, Rascher W 2002 Aerosolized perfluorocarbon suppresses early pulmonary inflammatory response in a surfactantdepleted piglet model. Pediatr Res 51:177-182

17. von der Hardt K, Kandler MA, Schoof E, Dotsch J, Bohle RM, Rascher W 2003 Laser-assisted microdissection and real-time PCR detect anti-inflammatory effect of perfluorocarbon. Am J Physiol Lung Cell Mol Physiol 285:L55-62
18. Fink L, Kinfe T, Seeger W, Ermert L, Kummer W, Bohle RM 2000 Immunostaining for cell picking and real-time mRNA quantitation. Am J Pathol 157:1459-1466

19. Fink L, Seeger W, Ermert L, Hanze J, Stahl U, Grimminger F, Kummer W, Bohle RM 1998 Real-time quantitative RT-PCR after laser-assisted cell picking. Nat Med 4:1329-1333

20. Kandler MA, von der Hardt K, Schoof E, Dötsch J, Rascher W 2001 Persistent improvement of gas exchange and lung mechanics by aerosolized perfluorocarbon. Am J Respir Crit Care Med 164:31-35

21. von der Hardt K, Kandler MA, Popp K, Schoof E, Chada M, Rascher W, Dotsch J 2002 Aerosolized adrenomedullin suppresses pulmonary transforming growth factorbeta1 and interleukin-1beta gene expression in vivo. Eur J Pharmacol 457:71-76

22. Lachmann B, Robertson B, Vogel J 1980 In vivo lung lavage as an experimental model of the respiratory distress syndrome. Acta Anaesthesiol Scand 24:231-236

23. Heid CA, Stevens J, Livak KJ, Williams PM 1996 Real time quantitative PCR. Genome Res 6:986-994

24. Fink L, Kinfe T, Stein MM, Ermert L, Hänze J, Kummer W, Seeger W, Bohle RM 2000 Immunostaining and laser-assisted cell picking for mRNA analysis. Lab Invest 80:327-333

25. van Kaam AH, De Jaegere A, Haitsma JJ, Van Aalderen WM, Kok JH, Lachmann B 2003 Positive pressure ventilation with the open lung concept optimizes gas exchange and reduces ventilator-induced lung injury in newborn piglets. Pediatr Res 53:245253

26. Gerstmann DR, Fouke JM, Winter DC, Taylor AF, deLemos RA 1990 Proximal, tracheal, and alveolar pressures during high-frequency oscillatory ventilation in a normal rabbit model. Pediatr Res 28:367-373

27. Bueno PC, Bueno CE, Santos ML, Oliveira-Junior I, Jr., Salomao R, Pinheiro BV, Beppu OS 2002 Ventilation with high tidal volume induces inflammatory lung injury. Braz J Med Biol Res 35:191-198

28. Parker JC, Hernandez LA, Peevy KJ 1993 Mechanisms of ventilator-induced lung injury. Crit Care Med 21:131-143

29. Tremblay L, Valenza F, Ribeiro SP, Li J, Slutsky AS 1997 Injurious ventilatory strategies increase cytokines and c-fos m-RNA expression in an isolated rat lung model. J Clin Invest 99:944-952

30. Wirtz HR, Dobbs LG 1990 Calcium mobilization and exocytosis after one mechanical stretch of lung epithelial cells. Science 250:1266-1269

31. Felix JA, Woodruff ML, Dirksen ER 1996 Stretch increases inositol 1,4,5 trisphosphate concentration in airway epithelial cells. Am J Respir Cell Mol Biol 14:296-301

32. Tsao PS, Lewis NP, Alpert S, Cooke JP 1995 Exposure to shear stress alters endothelial adhesiveness. Role of nitric oxide. Circulation 92:3513-3519

33. Vazquez de Anda GF, Hartog A, Verbrugge SJ, Gommers D, Lachmann B 1999 The open lung concept: pressure-controlled ventilation is as effective as high-frequency oscillatory ventilation in improving gas exchange and lung mechanics in surfactantdeficient animals. Intensive Care Med 25:990-996

34. Sawa T, Corry DB, Gropper MA, Ohara M, Kurahashi K, Wiener-Kronish JP 1997 IL-10 improves lung injury and survival in Pseudomonas aeruginosa pneumonia. J Immunol 159:2858-2866

35. Fink L, Kohlhoff S, Stein MM, Hänze J, Weissmann N, Rose F, Akkayagil E, Manz D, Grimminger F, Seeger W, Bohle RM 2002 cDNA array hybridization after laser-assisted microdissection from nonneoplastic tissue Am J Pathol 160:81-90

36. Betsuyaku T, Griffin GL, Watson MA, Senior RM 2001 Laser capture microdissection and real-time reverse transcriptase/polymerase chain reaction of bronchiolar epithelium after bleomycin. Am J Respir Cell Mol Biol 25:278-284 